\title{
Otizmli Kaynaştırma Öğrencilerinin Sınıflarında Akran İlişkilerinin Geliştirilmesine Yönelik Eğitim Programının Etkililiğinin İncelenmesi*
}

\section{The Examination of an Education Program to Improve Peer Relationships of the Autistic Children Integrated In Classrooms}

\author{
Semra Öztürk Özgönenel, Psk. Dr., Çağdaş Işık Özel Eğ. ve Reh. Merkezi, semraozturk2002@hotmail.com \\ Alev Girli, Yrd. Doç. Dr., Dokuz Eylül Üniversitesi, Buca Eğitim Fakültesi, Özel Eğ. Böl., alev.girli@deu.edu.tr
}

ÖZ. Bu çalışmada, ilköğretim okullarında birinci kademede eğitim alan otizm tanılı öğrencilerin akranlarıyla ilişkilerini, okula uyumlarını ve sosyal kabullerini artırmak amacıyla geliştirilmiş olan bir eğitim programının etkililiği incelenmiştir. Araştırma, İzmir ilinde bulunan beş ilköğretim okulunda 2011-2012 eğitim-öğretim yılında gerçekleştirilmiştir. Araştırma deseni olarak "ön test - son test kontrol gruplu yarı deneysel desen" ve nitel araştırma yöntemlerinden görüşme kullanılmıştır. Araştırmanın bağımsız değişkenini "eğitim programı", bağımlı değişkelerini akranların sosyal kabulleri, okula uyumları, öğretmen ve akran merkezli sosyal davranışları oluşturmaktadır. Verilerin toplanmasında; 'Sosyal Kabul Ölçeği', Sosyometri, “Öğretmen Görüşme Formu” ve Kişisel Bilgi Formu' kullanılmıștır. Bulgular, akran ilișkilerini geliştirmek üzere hazırlanmıș olan eğitim programının, akranların sosyal kabulleri ve otizmli öğrencilerin sosyal yeterlilik ve okula uyum davranışları üzerinde etkili olduğunu göstermiştir.

Anahtar Kelimeler. Kaynaştırma, otizm, sosyal kabul, sosyometri, okula uyum

\begin{abstract}
The aim of this research is to examine the effectiveness of an education program in order to increase the social acceptance, adaptation and peer relationships of children with autism integrated in first degree classrooms. The independent variable of the research is the "education program" and the independent variables are "social acceptance of peers, their adaptational process through schooling and the social behaviors based on teachers and peers. The data were collected by the quantitative and qualitative methods. During the collection of the data, Sociometric and Social Acceptance Scale, Teachers Form, and Personal Information Form were used. The data obtained from the research showed that, the educational program which designed to develop the peer relationships was effective on the peer acceptance and the social sufficiency of the students with autism, helping them to adjust themselves to the school by showing corresponding behaviours. In accordance with the data derived from the research, further investigations and applications were also suggested.
\end{abstract}

Keywords. Mainstreaming, autism, social acceptance, sociometric, adjustment level

\section{SUMMARY}

Purpose and Significance: Increasingly, educators are placing children with disabilities in regular classrooms, intending to enhance social as well as academic development. Weak social skills and lack of peer interaction are the main characteristics of children with Autistic Spectrum Disorder (ASD). Other characteristics include a failure of using eye gaze, facial expressions, body posture and gesture to regulate the social integration adequately (Attwood, 2000). Relevant research has put forth that students with autism who have weak relationships with their peers may result in their isolation and as a result cause feelings of loneliness (Bauminger, Shulman, \& Agam, 2003). The aim of this research is to examine the effectiveness of an education program in order to increase the social acceptance, adaptation and peer relationships of autistic children integrated in first degree classrooms.

Methods: The research was executed in five schools of MEB of Turkish government in Izmir, in the years of 2011-2012. The independent variable of the research is the "education program" and the independent variables are "social acceptance of peers", their adaptation process through schooling and the social behaviors based on teachers and peers. The data were collected by the quantities and

* Bu araştırma birinci yazarın doktora tezinden üretilmiştir. 
qualitative methods. The sample was given pre tests and post tests. During the collection of the data, to determine the students' social acceptance of integrated students "Sociogram" and "Social Acceptance Scale", to determine the teachers' observations among the integrated students' relationships with their peers "Teachers Form" and to collect the demographical data, "Personal Information Form" was used.

Education program is consisted of 11 activities to make the social acceptance to increase and came through in 13 course hours in two classrooms which are assigned as experiment group. This program was applied first of all as a pilot study in another school chosen by the researcher and in the light of the feedbacks it was revised and enriched by the researcher. The education program hasn't been given to the control group.

Results: The data obtained from the researched showed that, the educational program which designed to develop the peer relationships was effective on the peer acceptance and the social sufficiency of the students with autism, helping them to adjust themselves to the school by showing corresponding behaviors.

Conclusions: In accordance with the data derived from the research, further investigations and applications were also suggested. Planned studies should be carried out to develop the social status of students with autism. It is observed that there is a growing need for carrying out the longitudinal studies carried out abroad in Turkey. Comparative studies should be carried out for different age groups with wider sampling groups with regard to gender.

\section{GíRiş}

Özel gereksinimli bireyler için toplumsal yaşama katılımın ilk adımı olarak kabul edilen kaynaştırma uygulaması, yetersizlikten etkilenmiş öğrencilerin genel eğitim sınıflarında değişik zamanlı olarak akranlarıyla bir arada öğrenimini sürdürmesi için özel olarak yetişmiş personel ile özel eğitim ve destek hizmetler sağlanarak yapılan düzenlemeler olarak tanımlanmaktadır (Batu ve Kırcaali-İftar, 2006). Gerekli koşullar yerine getirildiğinde kaynaştırma hem özel gereksinimli öğrenciler hem de normal gelişim gösteren çocuklar için sosyal ve akademik anlamda pek çok fayda sağlamaktadır. Normal gelişim gösteren akranlarını model olmaları, özel gereksinimli çocukların daha iyi öğrenmelerine ve öğrendiklerini pekiştirmelerine fırsat sağlamaktadır (Batu ve Kırcaali-İftar, 2006; Lewis \& Doorlag, 1999; Sucuoğlu ve Kargın, 2006; Salend, 1998). Özel gereksinimli çocuğun ailesinden uzaklaşıp diğer bireylerle ve akranlarıyla ilişki kurması, çocuğa bağımsızlık duygusu aşılamakta, yeni uyarı kaynakları ve yeni davranış örnekleri sağlayarak dünyasını zenginleștirmekte, benlik kavramının gelişmesine yardımcı olmaktadır (Disalvo \& Oswalt, 2002; Leaf, Taubman, Bloomfield, Palos, Leaf, McEachin \& Oppenhaim, 2009; Akçamete ve Ceber, 1999). Ayrıca özel gereksinimli öğrencinin olumlu davranışlarını, dil, iletişim ve sosyal becerilerini geliştirmelerine katkı sağladığı görülmektedir (Gordon, Feldman \& Chiriboga, 2005; Osler \& Osler, 2002; Terpstra \& Tamura, 2008).

Ülkemizde, 1983 yılından bu yana uygulanan kaynaştırma uygulamaları çoğu zaman hiçbir özel eğitim önlemi almadan, düzenleme yapmadan ve programın öğelerinde uyarlamaya gitmeden yetersizlikten etkilenmiş öğrencilerin genel eğitim sınıfına yerleştirilmesi olarak gerçekleşmektedir (Batu ve Kırcaali-İftar, 2006; Özyürek, 2000). Oysaki başarılı bir kaynaştırma programı duygusal, akademik, fiziksel düzeyde her iki taraf için de uygun düzenlemeler yapmayı gerektirmektedir. Kaynaştırma uygulaması ile ilgili araştırmalar, kaynaştırma öğrencilerinin akranları tarafından sosyal kabulünü arttırmak amacıyla özel gereksinimli öğrencilerin hem akademik becerilerinin hem sosyal becerilerinin geliștirilmesi gerektiğini, aynı zamanda yalnızca özel gereksinimli öğrencilerle yapılacak çalışmaların sosyal kabul için yeterli olmadığını, kaynaştırma öğrencisinin sınıf arkadaşlarının empati becerilerinin geliştirilmesi gerektiğini de vurgulamaktadır (Batu, Kırcali-İftar, 2006). Bu tür müdahale programları engelli olmayan öğrencilerin farklılıklara hoşgörü gösterebilen, diğer insanlara duyarlı davranabilen, empati becerileri gelişmiş bireyler olmaları yönünde kişisel gelişimlerine katkıda bulunmaktadır (Avcıoğlu, 2005; Batu, Kırcali-İftar, 2006; Sucuoğlu ve Kargın, 2006). Yapılan çalışmalarda normal gelişim gösteren ve özel gereksinimli öğrencilerin birbirleri ile 
etkileşimleri sonucunda, normal gelişim gösteren çocukların kendilerine olan saygılarının da arttı̆̆ gözlenmiștir (Peck, Carlson \& Helmstetter, 1992; Staub, Peck, Gallucci \& Schwartz, 2000).

Konu ile ilgili yapılan araştırma sonuçları, özel gereksinimli öğrenciye yönelik tutumları ve sosyal kabulü olumlu yönde geliștirmek üzere planlı etkinlikler yapılmadığı takdirde kaynaştırma uygulamalarının sınıftaki diğer çocukların kabul düzeylerini arttırmadığı hatta varolan olumsuz tutumları daha da güçlendirebildiğini göstermektedir (Manetti, Schneider \& Siperstein, 2001; Westwood, 1997 akt. Sucoğlu ve Kargın, 2006). Özellikle ilköğretim çağındaki kaynaştırma öğrencilerinin oyun arkadaşı olarak tercih edilmediklerine, reddedildiklerine, zihinsel, sosyal ve duygusal gelişimlerinde olumsuz etkiye yol açabilen düşük bir statüde algılandıklarına ilişkin pek çok araştırma bulgusu vardır (Aktaş ve Küçüker, 2002; Vuran, 2005). Araştırmalar normal gelişim gösteren öğrencilerin özel gereksinimli bireylere yönelik olumsuz tutumlarının değiștirilmesinde, sosyal kabulün ve etkileşimin artırılmasında bilgilendirme, canlandırma ve kendini özel gereksinimli bireylerin yerine koyarak yaşantı sağlama gibi çalışmaların etkili olduğunu göstermektedir (Akfırat, 2004; Aktaş ve Küçüker, 2002; Civelek, 1990; Çiftçi, 2001; Şahbaz, 2007; Tekin, 1994; Uçar, 2008). Ülkemizde ilgili alan yazın tarandığında, son yıllarda kaynaştırma uygulamasından yararlanan öğrencilerin sosyal uyum düzeyleri, sosyal becerileri, arkadașlık ilișkileri ve sosyal kabulleri ile ilgili çalışmalarda artış olduğu (Alptekin, 2010; Arslan, 2010; Avcıoğlu, 2001; Çiftçi, 2001; Sucuoğlu ve Özokçu, 2005; Şahbaz, 2007; Yaşaran, 2009) ancak bu çalıșmaların nicelik olarak henüz yeterli sayıda olmadığı ve daha çok otizm spektrum grubunun dışındaki özel gereksinimi olan grupları konu edindiği gözlemlenmektedir.

Türkiye'de kaynaştırma uygulaması yürütülen sınıflarda eğitim alan özel gereksinimli öğrencilerin normal gelişim gösteren akranları tarafından sosyal kabul düzeylerini inceleyen araştırma sonuçları konuyla ilgili pek çok sorunu ortaya koymaktadır. Bu sorunlar; yetersizliğin arkadașlık yapma ve birlikte oyun oynama davranıșlarına engel olarak görüldüğü, akranların özel gereksinimli öğrencileri tembel, ders dinlemeyen, derste arkadaşlarını rahatsız eden öğrenciler olarak algıladıkları ve normal gelişim gösteren akranları tarafından çoğunlukla tercih edilmediği seklindedir (Girli ve Aksoy, 2012; Şahbaz, 2004; Vuran, 2005). Kabasakal ve arkadaşlarının (2007) yaptıkları bir başka çalışmada ilköğretimde kaynaştırma sürecinde olan özel gereksinimli öğrencilerin diğer öğrencilere göre daha fazla şiddetle karşılaştıkları, akranları tarafından diğer çocuklara nazaran daha az sevilen, en az tercih edilen ve arkadaşlarıyla iletişim problemleri olan bireyler olarak algılandıkları belirlenmiștir.

İlköğretime devam edebilecek düzeydeki otizmli öğrenciler, kaynaştırma için uygun koşullar sağlandığında ve yaşıtları tarafından kabul gördüklerinde kaynaştırma uygulamasından en fazla yarar sağlayabilecek gruplardan birisidir. Buna karşın otizmin doğasından kaynaklanan arkadaşlık ilişkisi geliştirme konusundaki isteksizlik, sosyal etkileşime uygun karşıllk verememe, sosyal ifadeleri çok iyi anlayamama, ilgileri ve başarıyı paylaşmada yetersiz kalma gibi özellikleri, bu gruptaki çocukların okuldaki akranlarıyla ilişkilerini olumsuz olarak etkilediği, çoğu zaman dışlanma ve yalnız kalma sorunu yaşadıkları belirtilmektedir (Attwood, 2000; Bauminger \& Kasari, 2000; Bauminger \& Shulman, 2003; Connor, 2000; Donnelly \& Bovee, 2003; Gordon, Feldman \& Chiriboga, 2005; Harrover \& Dunlap, 2001; Lane, 2004; Scwartz, 2000; Slaughter, Dennis \& Pritchard, 2002, Vickerstaff, Heriot, Wong, Lopes \& Dossetor, 2007). Ayrıca, bir çalışmada da otizmli öğrenciler öğretmenleri tarafından yüksek oranda çatışmacı olarak değerlendirilmişlerdir (Robertson et al., 2003).

Ülkemizde, sınırlı sayıda olmasına rağmen yapılan çalışmaların sonuçları otizmli öğrencilerin sosyal becerilerindeki yetersizlikleri nedeniyle arkadaşları tarafından dışlanma, yalnız kalma gibi sorunlarla karşılaşabildiklerini göstermektedir (Girli ve Atasoy, 2012; Uçar, 2008). Bu nedenle otizm ve Asperger sendromu tanılı öğrencilerinin kaynaştırma uygulaması sürecinde yaşadıkları sosyal kabul sorunlarının ve arkadaşlık ilişkilerinin araştırılmasına gereksinim olduğu görülmektedir. Elde edilecek verilerle, otizmli öğrencilerin sosyal uyum sorunları ve sosyal beceri yetersizlikleri belirlenebilecek ve bu alanlara yönelik eğitim programları geliștirilebilecektir. Bunun yanı sıra farklı öğretim yöntem ve teknikleri kullanarak uygulanacak sosyal kabul öğretim programlarının etkililiğinin araştırılmasının bu öğrencilerin sosyal kabullerini sağlamak için etkili programlar geliştirilmesine katkı sağlayacaktır. Bu çalışmanın amacı, ilköğretim okullarında birinci kademede kaynaştırma uygulaması kapsamında eğitim alan otizm tanılı öğrencilerinin akranlarıyla ilişkilerini, 
okula uyumlarını ve sosyal kabullerini artırmak amacıyla geliştirilmiş olan bir eğitim programının etkililiğinin incelenmesidir. Bu amaç doğrultusunda aşağıda yer alan sorulara yanıt aranmıştır

\section{YÖNTEM}

\section{Araştırma Deseni}

Bu araştırmada temel araştırma deseni olarak "ön test-son test kontrol gruplu yarı deneysel desen" seçilmiştir. Özellikle sosyal bilimlerde ve eğitim bilimlerinde deney ve kontrol grubunun seçkisiz (rastgele) atanmasının mümkün olmadığı durumlarda - ki şimdiki araştırmada bu durum söz konusudur- bu desenin kullanımının daha uygun olduğu belirtilmektedir (Yıldırım Şimşek, 2000). Ayrıca, araştırmada otizmli öğrencilerin sosyal uyum ve sosyal becerileri, arkadaşlık ilişkilerini ortaya koyabilmeye yardımcı olması amacıyla nicel verilerin yanı sıra öğretmen görüşleri nitel veri toplama tekniklerinden "görüşme" kullanılarak toplanmıştır.

\section{Çalışma Grubu}

Araştırmanın çalışma grubunu; İzmir ilinde merkez ilçelerde, sınıfında otizm tanılı kaynaştırma öğrencisi olan, uygulama kolaylığı ve aynı sosyo-ekonomik düzeyi temsil etme özelliği göz önünde bulundurularak seçilen, dört ilköğretim okulunun ilk kademesinin 4. ve 5. sınıf öğrencilerinden 120 öğrenci oluşturmaktadır. Deney grubunda bulunan toplam 49 öğrencinin 25’u kız 24'ü erkek öğrenciden; kontrol grubunda bulunan toplam 71 öğrencinin 29'u kız 42'si erkek öğrenciden oluşmaktadır.

\section{Bağımsız Değişkenler}

Bu araştırmanın bağımsız değişkenleri, araştırmacı tarafından geliştirilen "eğitim programı" ve sosyo-demografik değişkenlerdir. Sosyo demografik değişkenler olarak cinsiyet, doğum sırası ve anne/baba eğitim düzeyi seçilmiştir.

Eğitim programının geliştirilmesi

Araştırmada, ilgili alan yazın taranarak birinci araştırmacı tarafından geliştirilen bir program kullanılmıştır. Önce bir pilot program hazırlanmıştır. On bir oturum olarak planlanan eğitim programının pilot uygulamaları 2011 eğitim-öğretim yılında gerçekleştirilmiştir. Pilot uygulama sonuçları değerlendirilerek programın içeriği, etkinliklerin süreleri, sıraları ve sayıları yeniden düzenlenmiştir. Bu düzenlemeyle etkinlik sayısı arttırılarak 14'e yükseltilmiş ve otizm konusunda bilgilendirici ek bir oturum programa eklenmiştir. Hazırlanan etkinlikler ilköğretim okulu ilk kademede okuyan dördüncü ve beşinci sınıf öğrencilerinin yaş düzeyine uygun olarak düzenlenmiştir. Kategoriler oluşturulurken otizmli öğrencilerin en çok zorlandıkları sosyal iletişim ve etkileşim becerileri dikkate alınmıştır. Etkinlikler; dört kategoride toplanmaktadır. 1. Temel sohbet becerilerini geliştirmeye yönelik etkinlikler 2. Empati ve toleransı geliştirmeye yönelik etkinlikler 3. Akran ilişkilerini geliştirme diğerlerinin olumlu özelliklerini fark etme ve ifade etme etkinlikleri 4. Öfkeyle baş etme etkinlikleri.

\section{Bağımlı Değişkenler}

Araştırmanın bağımlı değişkenlerini akranların sosyal kabulleri, otizmli öğrencilerin okula uyumları, öğretmen merkezli sosyal davranışları ve akran merkezli sosyal davranışları oluşturmaktadır.

\section{Veri Toplama Araçları}

Araştırma verileri nicel ve nitel teknikler kullanılarak toplanmıştır. Otizmli öğrencilerin akranları tarafından sosyal kabullerini değerlendirmek üzere "sosyal kabul ölçeği", "sosyometri" öğretmenlerin kaynaştırma öğrencisinin arkadaşlık ilişkileri konusundaki gözlem ve görüşlerini belirlemek için "Öğretmen Gözlem ve Görüşme Formu" kullanılmıştır. Öğrencilerin demografik bilgilerini almak amacıyla "Öğrenci Bilgi Formu” kullanılmıştır.

Sosyal Kabul Ölçeği (SKÖ)

Sosyal Kabul Ölçeği (Social Acceptance Scale) Siperstein tarafından tutumların bileşenleri arasında yer alan davranışsal boyutu ölçmek amacıyla geliştirilen 22 maddeden oluşan bir ölçektir.(akt; Civelek, 1990) Ölçekte yer alan maddelere verilen tepkiler "Evet", "Sanırım Evet", "Ne Evet Ne Hayır", "Sanırım Hayır" ve "Hayır" ş̧eklinde derecelendirilmiştir. Ölçeğin puanlanması 0-5 arasındadır. Ölçekten alınabilecek en düşük puan 22 ve en yüksek puan 110'dur. Yüksek puanlar özel gereksinimli bireylere yönelik sosyal kabul düzeyinin yüksek olduğunu göstermektedir. Ölçeğin 
Türkçe'ye kazandırılması Civelek (1990) tarafından yapılmıştır. Ölçek önce Türkçe’ye çevrilmiş daha sonra uzman grubunun görüşleri dikkate alınarak düzenlemeler yapılmıştır. Aynı zamanda uzman grubundan testin sosyal kabulü ölçtüğüne ilişkin alınan dönütlere dayalı olarak testin kapsam geçerliğinin olduğu düşünülmüştür. Bu çalışmadan sonra ölçek, 83 engelli olmayan öğrenciye bir ay ara ile uygulanmış ve güvenirlik katsayısı 0.83 olarak bulunmuştur. Yapılan bu çalışmalar sonunda Civelek (1990), aracın geçerli ve güvenilir bir ölçek olduğu sonucuna varmıştır. Civelek (1990), aynı araştırmasında ölçeğin diğer engel gruplarına yönelik sosyal kabulü belirleme çalışmalarında da kullanılabileceğini belirtmektedir (Aktaş ve Küçüker, 2002). Tekin'in (1994), yaptığı güvenirlik çalışmasında ilköğretim dördüncü sınıfa devam eden 26 öğrenci ile test tekrar-test güvenirliğini 0.82 olarak hesaplanmıştır. Bu çalışma için elde edilen iç tutarlık katsayısı .89 olup madde- toplam puan korelasyonları 20 ile.69 arsında değişmektedir.

Sosyometri

Ülkemizde de 1960'lı yıllardan itibaren kullanılmaya başlamış olan Sosyometri tekniği J. L. Moreno tarafından geliştirilmiştir. Bir gruptaki bireylerin birbirleriyle olan ilişkilerini ve etkileşim örüntüsünü saptamak amacıyla kullanılan sosyometri, bir grup tekniği olarak işlev görerek, grubun yapısını, alt grupları, lider ve izole edilmiş üyeleri ortaya çıkarmaktadır. Test-tekrar test güvenirliliği; İlkokul 4. ve 5. sinıflara devam eden 120 erkek ve 116 kız toplam 236 öğrenciye 4 hafta arayla iki kez uygulanan test puanlarıyla arasındaki ilişki Pearson Momentler Çarpımı tekniği ile hesaplanan güvenirlilik katsayısı 4. sınıflar için .85; 5. sınıflar için .88 ve tüm grup için .86 olarak bulunmuştur (Öner, 2006). Sosyometrik ölçme teknikleri uygulanarak elde edilen bilgiler, öğrencinin sosyal kabul ve reddi, saldırgan davranışları gibi bazı davranışları hakkında da bilgi toplamaya yardımcı olur (Çiftçi, 2001). Bu çalışmada öğrencilerden, olumlu ve olumsuz akran atamaları yapmaları istenmiştir. Tüm sınıfa sosyometri cevap kağıdı dağıtılmış ve öğrencilerin; "birlikte olmaktan en çok hoşlandıkları üç arkadaşları"nın isimlerini ve "birlikte olmaktan en az hoşlandıkları üç arkadaşları"nın isimlerini sırasıyla yazmaları istenmiştir.

Öğretmen Görüşme Formu

Nitel teknikler, bir alanda derinlemesine veri toplanmasını içeren bir araştırma biçimidir. Nitel araştırmada en yaygın olarak kullanılan üç tür veri toplama yöntemi vardır: görüşme, gözlem ve yazılı dokümanların incelenmesi (Yıldırım ve Şimşek, 2006). Bu çalışmada da araştırmanın nitel verilerini toplamak amacıyla öğretmenlerin kaynaştırma öğrencisinin arkadaşlık ilişkileri ve sosyal kabullerine ilişkin gözlem ve görüşlerini belirlemek için araştırmacı tarafından yarı yapılandırılmış bir görüşme formu oluşturulmuştur. Bu görüşme formları hazırlanmadan önce alan yazın taraması yapılarak formda yer alabilecek olası görüșme soruları oluşturulmuștur. Görüşme soruları hazırlandıktan sonra otizmli çocuklarla alanda çalışan doktora düzeyinde eğitimi olan iki uzmandan görüş alınmış ve görüşler doğrultusunda sorular gözden geçirilerek 20 tane olan soru sayısı 16'ya düşürülmüş ve bazı soru içerikleri yeniden düzenlenmiştir (Ek:1).

Öğrenci Bilgi Formu

Çalışma grubunda yer alan öğrencilerin demografik özelliklerine ilişkin bilgilerin toplanması amacıyla araştırmacı tarafından geliştirilen "Öğrenci Bilgi Formu" kullanılmıştır. Bu formla öğrencilerin cinsiyeti, doğum sırası, anne/baba eğitim düzeyi ve kardeş sayılarıyla ilgili bilgiler toplanmıştır.

\section{Veri Toplama Süreci / İşlem}

Eğitim programı başlamadan bir hafta önce öğrencilerin ön test uygulaması yaklaşık 40 dakika sürmüştür. Tüm ölçeklerin açıklama bölümündeki bilgiler araştırmacı tarafından öğrencilere açıklanmış, formları nasıl işaretleyecekleri gösterilmiș ve soruları yanıtlanmıştır. Öğrencilerin bu formları bağımsız olarak işaretlemelerine dikkat edilmiştir. Ön test uygulamasından bir hafta sonra deney grubu ile ilk oturum yapılmış ve ders süresinin ilk 10 dakikasında çalışmanın amacı, çalışma ve kurallar açıklandıktan sonra birinci etkinliğin uygulaması başlatılmıştır.

Eğitim programı, öğrencilerin devam etmekte oldukları sınıf ortamında gerçekleştirilmiştir. Deney gruplarına eğitim uygulaması 11 hafta sürmüştür. Bu süre boyunca kontrol grubu ile çalışma yapılmamıştır. Eğitim programı tamamlandıktan bir hafta sonra son test uygulaması yapılmıştır.

Öğretmen görüşme formları araştırmacı tarafından eğitim programı öncesi ve sonrasında eğitimcilerle bireysel görüşme yapılarak doldurulmuştur. Bir görüşme ortalama $30 \mathrm{dk}$ sürmüştür. 


\section{Veri Çözümleme Teknikleri}

$\mathrm{Bu}$ çalışmada nicel verilerin çözümlemesi SPSS 17.0 paket programı kullanılarak gerçekleştirilmiştir, Bağımsız değişkenlerin bağımlı değişkenler üzerindeki etkisini saptamak üzere tekrarlayan ölçümler için varyans analizi ve çoklu regresyon analizi teknikleri kullanılmıştır. Varyans analizleri sonrasında farklılaşmaların kaynağını saptamak üzere izleme testi olarak t testlerinden yararlanılmıştır. Araştırmada kullanılan tüm istatistiksel testlerde .05 anlamlılık kriteri kullanılmıştır.

Bu çalışmada nitel verilerin analizi tümevarım analizi tekniğiyle analiz edilmiştir. Var olan bilgiler azaltılma amaçlı organize edilerek kategorilere ayrılmış ve kodlanmıştır. Kodlamaların ardından temaların oluşturulması işlemine geçilmiştir. Verilerin dört tema altında toplandığı görülmüştür.

\section{BULGULAR}

Bu çalıșmada, deney grubunda yer alan sınıflarda, araștırmacı tarafından akran ilișkilerinin geliştirilmesi amacıyla uygulanmış olan eğitim programının, otizmli öğrencilerin sosyal kabul düzeylerinde artış sağlayıp sağlamadığı ve akran ilişkilerinin geliştirilmesinde etkili olup olmadığı incelenmiştir.

Araştırmada uygulanan eğitim programının kaynaştırma sınıfında yer alan öğrencilerin sosyal kabul düzeyleri üzerinde herhangi bir etki yaratıp yaratmadığı 2 (grup: deney grubu $\times$ kontrol grubu) $\times 2$ (zaman: ön-test x son-test) karışık desen ANOVA ile incelenmiştir. Buna göre deney ve kontrol gruplarının ön- test ve son- test puanlarının değişimi istatistiksel açıdan anlaml, $F_{1,108}=25.58$ $p<.001 \eta^{2}=.19$ bir şekilde farklılaşmaktadır. Farklılaşmanın kaynağını araştırmak üzere Bonferroni yaklaşımı kullanılarak gerçekleştirilen bağlantılı örneklemler için t-testi sonucuna göre; deney grubunun ön testte elde edilen sosyal kabul ortalaması ( $\bar{X}=85.19$, ss. $=14.85)$ ile son testte elde edilen sosyal kabul ortalaması ( $\overline{\mathrm{X}}=95.83$, ss. $=10.47)$ arasında istatistiksel açıdan anlamlı bir fark bulunduğu $t_{46}=6.81 \mathrm{p}<.001$ görülmüştür. Kontrol grubunun ön testte elde edilen sosyal kabul ortalaması ( $\overline{\mathrm{X}}=85.78$, ss. $=14.35)$ ile son testte elde edilen sosyal kabul ortalaması $(\overline{\mathrm{X}}=84.38$, ss. $=$ 15.07) arasında istatistiksel açıdan anlamlı bir fark olmadığı görülmüştür, $t_{62}=.82 \mathrm{p}=.41$. Grupların ön-test son-test puanları Şekil-1'de gösterilmiştir.

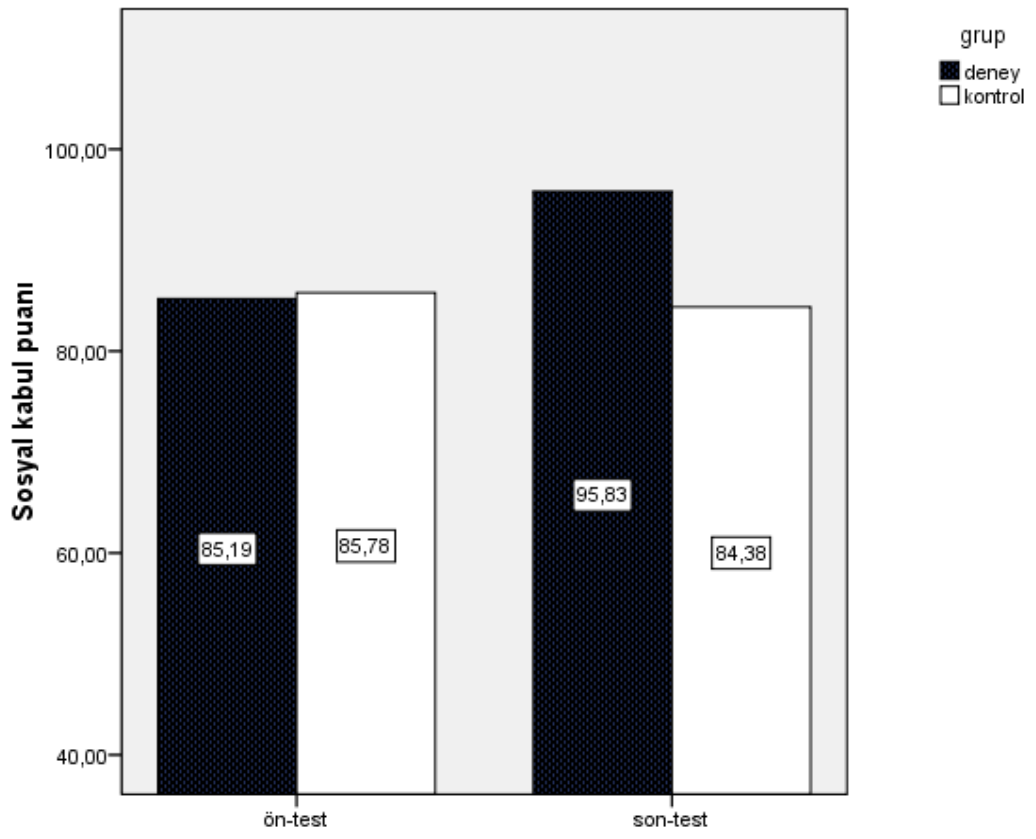

Şekil 1. Deney ve Kontrol Gruplarının Ön-Test ve Son-Testte Aldıkları Sosyal Kabul Puanları

Deney ve kontrol grubundaki akranların son-testte ve ön-testte aldıkları sosyal kabul puanları arasındaki farkı, yani sosyal kabul puanlarındaki değişmeyi yordayan değişkenlerin neler olduğunu belirlemek amacıyla çoklu doğrusal regresyon analizi gerçekleştirilmiştir. Söz konusu 
analizde, sosyal kabul ön-test puanı bağımlı değişken; cinsiyet, yaş, annenin eğitim düzeyi, babanın eğitim düzeyi, kız kardeş sayısı, erkek kardeş sayısı, doğum sırası ise bağımsız değişkenler olarak alınmıștır (Bkz. Tablo1).

Tablo 1. Sosyal Kabul Düzeylerindeki Değisşmeyi Yordayan Faktörler

\begin{tabular}{lccc}
\hline Yordayıcı Değissken & $\boldsymbol{\beta}$ & $\mathbf{t}$ & $\mathbf{p}$ \\
\hline Grup (Deney veya kontrol) & -.40 & 4.48 & .000 \\
Cinsiyet & .04 & .41 & .68 \\
Yaş & -.07 & .76 & .45 \\
Annenin eğitim düzeyi & -.15 & 1.13 & .26 \\
Babanın eğitim düzeyi & .21 & 1.67 & .10 \\
Kız kardeş sayısı & .07 & .61 & .54 \\
Erkek kardeş sayısı & .08 & .62 & .54 \\
Doğum sırası & .04 & .23 & .82 \\
\hline
\end{tabular}

Tablo 1'de görüldüğü gibi toplam sosyal kabul varyansının \%24'ünü açıklayan tek bir değişken F8,101=3.92 p<.001 eğitim programına katılma değişkenidir. Yani sosyal kabul puanlarındaki değişmeyi açıklayan tek faktör deney ya da kontrol grubunda bulunmaktır. Bu analiz eğitim programının gücünü göstermesi açısından önemlidir. Buna göre farklı sosyo-demografik özelliklere sahip gruplar eğitimden eşit düzeyde yararlanmışlardır.

Sosyometri sonuçları seçme ve reddedilme parametreleri üzerinden yorumlanmıștır. Sosyometrik statüyü belirlerken hem özel gereksinimli öğrencinin seçilme sayısına hem de aldığı toplam sosyometri puanına bakılmıştır.

Tablo 2. Deney ve Kontrol Gruplarındaki Otizmli Öğrencilerin Ön Test-Son Test Sosyometri Puanları ve Seçilme Sayıları

\begin{tabular}{|c|c|c|c|c|c|c|c|c|c|}
\hline & & \multicolumn{2}{|c|}{ Deney Grubu 1} & \multicolumn{2}{|c|}{ Deney Grubu 2} & \multicolumn{2}{|c|}{ Kontrol Grubu 1} & \multicolumn{2}{|c|}{ Kontrol Grubu 2} \\
\hline & & Ön Test & $\begin{array}{l}\text { Son } \\
\text { Test }\end{array}$ & Ön Test & $\begin{array}{c}\text { Son } \\
\text { Test }\end{array}$ & Ön Test & $\begin{array}{l}\text { Son } \\
\text { Test }\end{array}$ & Ön Test & $\begin{array}{l}\text { Son } \\
\text { Test }\end{array}$ \\
\hline \multirow{2}{*}{ Seçilme } & Puanı & 2 & 9 & 0 & 6 & 0 & 0 & 0 & 0 \\
\hline & Sayısı & 2 & 5 & 0 & 4 & 0 & 0 & 0 & 0 \\
\hline \multirow{2}{*}{ Reddedilme } & Puanı & -6 & -2 & 0 & -4 & -6 & -5 & -2 & -2 \\
\hline & Sayısı & 2 & 1 & 0 & 2 & 2 & 2 & 1 & 1 \\
\hline
\end{tabular}

Tablo 2 incelendiğinde, deney ve kontrol grubundaki öğrencilerin sosyometri ön test puanları birbirleriyle çok yakınken, son testlerde deney grubunda bulunan otizmli öğrencilerin hem akranları tarafından seçilme sayısında hem de aldığı puanlarda artış olmuştur. Kontrol grubundaki kaynaştırma öğrencilerinin sosyometrik statülerinde ise herhangi bir değişiklik gözlenmemiştir. Bu sonuçlara göre akran ilişkilerinin geliştirilmesine yönelik olarak hazırlanan eğitim programının otizmli kaynaştırma öğrencisinin sosyometrik statüsü üzerinde olumlu etkisi olduğu görülmektedir.

Araştırmanın nitel bulguları da, nicel verilerden elde edilen bulguları destekler niteliktedir. Sınıf öğretmenlerinin otizmli öğrencilerin oyun, arkadaşlık, okula uyum ve iletişim becerileri hakkındaki görüşlerine yönelik cevaplar dört tema etrafında toplanmıştır. Birinci Tema: oyun becerileriyle ilgili, İkinci Tema, arkadaşlık becerileriyle ilgili; üçüncü tema: sınıf kuralları ve etkinliklere katılım (okula uyum) becerileriyle ilgili; Dördüncü Tema, iletişim becerileriyle ilgili öğretmen gözlem ve görüşleridir.

Öğretmenleri, deney grubundaki öğrencilerin lehine pozitif gelişmeler olduğunu belirtmişlerdir. Örneğin, eğitim programından önce birinci tema olan oyun becerilerine ilişkin D1'için öğretmeni "daha önceki yıllarda oyunlarına davet ediyorlardı artık vazgeçtiler. D1 oyunlarda sıra bekleyemiyor ve paylaşmıyor" ifadesi ile oyunlarda arkadaşlarının kabullerini açıklamıştır. Eğitim programı sonrasında ise,

D1 için öğretmeni bu durumu "oyuna davet ediliyor, bu programdan sonra çocukların ilgisinde ve kabulünde artış oldu, katılımı için daha ısrarcılar. Sinıftan birisi onu kullanmaya kalkarsa diğerleri hemen müdahale edip engel oluyorlar" ifadesi ile açıklamıștır. 
Kontrol grubundaki K1' in öğretmeni bu alandaki sorunlara örnek olarak 'Daha çok kız öğrenciler onu çağırıyor ama bir süre sonra çıkarıyorlar. Oyunu sürdüremiyor. Erkekleri uyarmam gerekiyor arkadaşınızı da oyuna alın diye" ifadesini kullanmıştır. K1'in öğretmeni, "Cocuklar artık onu çağırmaktan vazgeçti. Bazı arkadaşları onu kullanıyor. Pipini göster demişler o da göstermiş benim sonra haberim oldu çok kızdım hepsine" örneği ile aradan geçen sürede değişiklik olmadığını açıklamaya çalışmıştır.

İkinci tema olan, otizmli öğrencilerin arkadaşlık becerileri hakkında deney grubundaki D2'nin öğretmeni eğitim uygulanmadan önce 'Yakın arkadaşı yok, daha çok erkek çocuklar kısa süreli ilgilenir. Gruba katılmak için kendi istekte bulunsa bile kurallara uymuyor kafasına göre oynamaya çalışıyor. Çocuklar da onu istemiyor' ifadesini kullanmıştır. Sonra ise 'yöneldiği bir arkadaşı var o da onunla oynuyor. Sikılsa bile bakıyorum devam ediyor oynamaya' cümlesiyle olumlu değişikliği belirtmiştir.

Kontrol grubundaki K2'nin öğretmeni ise "arkadaş olarak seçtiği 2 kişi var K2 onlarla oynamayı talep eder, benim uyarımla onlar da yanlarına alırlar ben gözden kaybolunca birakıyorlar. Onun da gruba katılmak gibi bir çabası yok' ifadeleriyle durumu açıklamıștır. Kontrol grubundaki öğretmenlerin gözlemleri değişmezken deney grubundaki öğretmenler kaynaştırma öğrencisinin tercih ettiği arkadaşı tarafından kabul gördüğünü, teneffüslerde onu yanlarında götürdüklerini, oyundan çıkarsa onu yönlendirmeye çalıștıklarını belirtmişlerdir. Sınıfın empati becerilerinin arttığını, artık kaynaştırma öğrencisinin kontrolsüz davranışlarını şikayet konusu yapmayıp kendi aralarında çözmeye çalıştıklarını belirtmişlerdir.

Üçüncü tema olan okula uyumla ilgili olarak, eğitim uygulanmadan önce D2'ın öğretmeni "Rutin dersi takipte zorlanıyor. bir șeylerle oynuyor. Öfkelenince bağırır vurur. Bazen kendine de vurur" demiștir. Eğitimden sonra ise, "Tüm sınıf onu davet etmeye başladı, kimse grubuna katılmasına itiraz etmez. Kuralların farkına varmaya başladı hatta diğerlerini şikayet ediyor, öğretmenim parmak kaldırmadan konuştu gibi. Dersler ağırlaşınca yapamama duygusu onu öfkelendiriyor ama diğer çocuklar çok yardımcı, bana duyurmadan ona cevabı fisıldıyorlar" örneği ile değişiklikleri özetlemiştir.

K2' nin öğretmeni "tüm kuralları kavramıştır hepsine uyar. Derse katılmaya çalışır söz alır ama konuyla ilgisi olmayan sorular sorar. Hiç öfkelendiğine tanıklık etmedim" ifadesini kullanmıştır. K1'ın öğretmeni "bu yıl çocuklar onunla çalışmayı daha az talep ediyorlar. Sinıf kurallarına uyar, görsel derslere daha iyi katıllyor" örneğini vermiştir.

Sınıf öğretmenlerinin otizmli öğrencilerinin iletişim becerileri hakkındaki gözlemleri son test'de deney ve kontrol grupları için farklılaşmaktadır. Kontrol grubundaki öğrencilerin öğretmenlerinin gözlemleri ön test sonuçlarıyla paralellik gösterirken deney grubundaki öğrencilerin öğretmenleri kaynaştırma öğrencisinin bazı iletişim becerilerini kullanmaya başladıklarını belirtmişlerdir. Göz teması, iletişim mesafesi, sıra alarak konuşma gibi sohbet becerilerini daha iyi takip edebildiklerini belirtmişlerdir. Diğer iletişim becerilerinde dikkate değer bir gelişme gözlememişlerdir. D1'ın öğretmeni eğitim uygulanmadan önce "Diğerlerinin ilgilerinin farkında değil kendi ilgilendiği konular hakkında konuşur" ifadesini kullanırken; eğitimden sonra "Göz teması biraz daha iyi arkadaşları da D1 bana bak diye uyarmaya başladı" ifadesi ile değişikliği açıklamıştır. K1'ın öğretmeni ise "Hiç böyle bir farkındalığı yok" ifadesiyle arkadaşlarının ilgileri ve ne yaptıklarıyla ilgilenmediğini "durumda değişiklik yok" ifadesiyle de geçen süre içinde bu becerilerde değişiklik olmadığını belirtmiştir.

\section{TARTISSMA ve SONUC}

$\mathrm{Bu}$ çalışmada alan yazında birçok çalışma sonucunda da gösterildiği gibi (Chamberlain, Kasari \& Rotheram-Fuller, 2007, Donnelly \& Bovee, 2003, Vickerstaff, Heriot, Wong, Lopes \& Dossetor, 2007; Webster \& Carter, 2007) kaynaştırma sürecinde olan otizmli öğrencilerin sınıflarındaki akranları tarafından yeterince sosyal kabul görmediği, hem sosyal kabul ölçeği, hem sosyometri sonuçları ile belirlenmiştir. Ancak uygulanan eğitim programının sosyal kabulü arttırmada etkili olduğu belirlenmiștir. Akranların cinsiyet, yaş, kardeş sayısı gibi özellikleri sosyal kabul üzerinde etkili bulunmamıștır. Bu bulgu sosyal kabule yönelik eğitim programlarının en azından ilköğretim birinci kademedeki çocuklar üzerinde cinsiyet farklılıklarından etkilenmediğini gösteren alan yazın bulguları ile tutarlıdır. Örneğin benzer bir çalışmada (Uçar, 2008) otizmli kaynaştırma öğrencilerine 
yönelik kabul edici tutum geliştirme programı uygulanan ilköğretim birinci kademe öğrencileri arasında cinsiyet değişkenine göre anlamlı farklılık bulunmamıștır.

Alan yazında özel gereksinimli bireylere yönelik sosyal kabulü belirleyen tutumların değiştirilmesinde farklı uygulama tekniklerinin bir arada kullanımı önerilmektedir. Bu çalışmada da benzer şekilde bilgi verme, canlandırma ve tartışma tekniklerinin bir arada kullanıldığı etkinlikler kullanılmış ve etkili olduğu görülmüştür. Bu sonuçlar, Alptekin (2010), Çiftçi (2001), Manetti, Schneider \& Siperstein (2001) ve Şahbaz' in (2004) zihinsel yetersiz, Krahe \& Altwasser (2006) ve Aktaş ve Küçüker'in (2002) fiziksel yetersiz öğrencilerin sosyal kabul için bilgilendirme ve etkileşim yöntemlerinin birlikte kullanımının etkili olduğunu gösteren çalışmalarıyla tutarlılık göstermektedir. Benzer şekilde, Alptekin (2010) birlikte eğitim ortamına devam eden zihinsel yetersizliği olan öğrencilerin sosyal becerileri kazanmasına yol açan "akranların model olarak etkileşimde bulunmasını" incelediği araștırmasında akranların sosyal kabullerinin artığını bulmuștur. Civelek'in (1990) çalışmasında; bilgilendirme, canlandırma ve tartışma tekniklerinin birlikte kullanıldığı eğitim programının etkili olduğu görülmüştür. Tekin (1994), Yaşaran (2009), Batu ve Uysal (2006) farklı tanı gruplarıyla yaptıkları çalışmalarda "Sosyal Kabul Ölçeği”ni kullanarak yaptıkları eğitim uygulamalarının sosyal kabulü arttırdığını belirlemişlerdir.

$\mathrm{Bu}$ araştırmada hem otizmli kaynaştırma öğrencisinin tanıdan kaynaklı iletişim becerilerindeki yetersizliklerini gidermeye yönelik hem de normal gelişim gösteren akranların empati becerilerini geliștirmeye yönelik etkinlikler, bilgilendirici oturumlar birlikte planlanıp uygulanmıştır. Baumunger \& Kasari (2000) yaptıkları çalışmalarda normal gelişen çocukların tutumlarının değişmesinde, farklı gelişen çocuklarla yalnızca etkileşimde olmanın yeterli olmadığını göstermiştir. Yine Cook \& Semmel (1999) normal gelişen çocukların, etkileşim ve bilgilendirme dışında farklı gelișen akranlarıyla ortak yönlerinin fark edilmesinin de onları kabul etmedeki tutumlarını etkilediğini savunmuşlardır. Bu çalışmada da bilgilendirme, canlandırma, film izleme ve tartışma tekniklerinin bir arada kullanılmasının sosyal kabulün artırılmasında etkili olduğu görülmektedir.

Ülkemizde, alan yazın incelendiğinde özel gereksinimli ve normal gelişim gösteren öğrencilerin birlikte yer aldığı sosyal kabul çalışmalarının oldukça sınırlı sayıda olduğu görülmektedir (Avcıoğlu, 2001; Çolak, 2007). Yurtdışında yapılan ilk çalışmalarda, akranlar arasındaki sosyal etkileşim davranışlarının artırılmasını hedefleyen araştırmaların daha çok sınıf dışında yürütülmesinin sınırlılıklarından bahsedilirken (Odom \& Strain,1984), sonraki yıllarda çocukların doğal ortamları içersinde özellikle oyun etkinliklerinde gerçekleştirilen çalışmalarda daha etkili sonuçlar alındığı bildirilmiştir (Goldstein \& Cisar, 1992; Farrell, 2000; Krahe \& Altwasser, 2006). Bu çalışmanın da sınıf içinde ve tüm sınıfla yürütülmüş olmasının çalışmanın güçlü yönlerinden biri olduğu ve programın etkili olmasına katkısı olduğu düşünülmektedir. Ayrıca çalışmanın rehberlik saatinde yürütülmesi, birlikte oyunlara fırsat vermesi, tüm çocukların kendi duygularını tanımaya yönelik etkinlikler içermesi, olumlu sosyal etkileşimlere firsat veren bir sınıf atmosferi oluşmuş olmasının da elde edilen sonuçlarda etkisi olabilir.

Sosyometri sonuçları da sosyal kabul ölçeği ile elde edilen verilerle paralellik göstermiştir. Buna göre, deney ve kontrol grubundaki öğrencilerin ön test puanları birbirleriyle çok yakınken, son testlerde deney grubunda bulunan otizmli öğrencilerin hem akranları tarafından seçilme sayısında hem de aldığı puanlarda artış olmuştur. Kontrol grubundaki kaynaştırma öğrencilerinin sosyometrik statülerinde ise herhangi bir değișiklik gözlenmemiștir. Bu sonuçlara göre akran ilișkilerinin geliştirilmesine yönelik olarak hazırlanan eğitim programının otizmli kaynaștırma öğrencisinin sosyometrik statüsü üzerinde olumlu etkisi olduğu söylenebilir.

Öğretmenlerin görüşlerine ilișkin nitel verilerin analizinde deney grubunda yer alan iki otizmli öğrencinin öğretmenleri sosyal uyum, akran ilişkileri ve kurallara uyma gibi sosyal becerilerinde olumlu değişikler bildirmişlerdir. Ancak kontrol grubundaki çocukların öğretmenleri otizmli öğrencilerin sosyal yeterliklerinde herhangi bir gelişme gözlemlemediklerini belirtmişlerdir bu sonuçlar hem bu çalışmada sosyal kabul ölçeği hem de sosyometri ile elde edilen verileri destekler niteliktedir. Ayrıca, benzer araştırma bulgularıyla da benzerlik göstermektedir (Batu, 2000; Lewis \& Doorlag,1987; Salend,1998).

Sonuç olarak, araştırma bulguları Türkiye'de ve dünyada kaynaştırma sürecinde sosyal kabulle ilgili yapılan araştırmaların bulgularıyla paralellik göstermektedir. Bu araştırma kaynaştırma 
sürecinde bulunan otizmli öğrencilerin normal gelişim gösteren akranları tarafından kabul görebilmeleri için, arkadaşlık ilişkilerini ve empati becerilerini geliştirmeye yönelik çalışmaların arttırılmasına gereksinim olduğu yönündeki görüşleri desteklemektedir.

Alanda yapılan çalışmaların pek çoğu, sosyal beceri öğretimi ve sosyal yeterliliği artırarak sosyal kabulün artmasını sağlamak yönündedir (Aktaş ve Küçüker, 2002; Avcıoğlu, 2005; Baker, 2003; Cook \& Semmel, 1999; Farmer, Pearl \& Acker, 1996; Hogborg, 1987; Kamps, et al, 1992; Kargin ve diğer., 2003; Matson, Matson \& Rivet, 2000, Akt.Çolak, 2007; Ünsal, 2007; Roeyers, 1995; Sasso et al, 1986). Sosyal becerilerin, sosyal yeterliliklerin tespiti, öğretimi ve genellenmesi oldukça yapılandırılmış çalışmalara, kapsamlı düzenlenmiş destek özel eğitim hizmetlerine ve uzman desteklerine ihtiyaç duyan çalışmaları/yatırımları içermektedir. Ülkemiz gerçeği ve kaynaştırmada yaşanan sayısız sorunlar düşünüldüğünde engelli bireylere yönelik olarak yapılacak olan, sosyal becerileri kazandırmayla ilgili çalışmaların planlanması, uygulanması, yurt bazında yaygınlaştırılması için oldukça uzun zamana, ciddi yatırımlara ve yetişmiş personele ihtiyaç olduğu görülmektedir.

Bu çalışmanın sonuçları ışığında araştırmacılara yönelik şu önerilerde bulunulabilir:

1. Özellikle sosyal iletişim ve dil becerilerindeki yetersizlikleri dolayısıyla, sosyal becerileri edinim ve genellemede oldukça sınırlılıkları olan otizmli öğrencilerin kaynaştırma sürecinde sosyal kabullerinin sağlanabilmesi için akran kabullerinde etkili olan tutumların duygusal ve bilişsel süreçlerini etkilemeyi öne çıkaran programların uygulanması ve sonuçlarının değerlendirilmesi.

2. Akran ilişkilerini geliştirmeye yönelik olarak hazırlanmış olan etkinliklerin uygulamaları sonucunda meydana gelen değişikliğinin kalıcılığını belirlemek amacıyla izleme çalışmaları yapilabilir.

3. Normal gelişim gösteren öğrencilerin otizmli bireylere yönelik kabullerinin günlük yaşam içerisindeki davranışlarına yansımasını inceleyen gözleme dayalı farklı çalışmalar yapılabilir. Böylece deneysel olarak elde edilmiş sonuçların ekolojik geçerliğini test etmek mümkün olabilir.

4. İleri araştırmalarda ilköğretimin farklı sınıf düzeylerine uygun programlar hazırlanıp etkililiği çalışılabilir.

Araştırmadan elde edilen bulgular doğrultusunda uygulamaya yönelik şu önerilerde bulunulabilir.

1. Araştırmada uygulanan akran ilişkilerini geliştirmeye yönelik olarak hazırlanmış olan etkinlikler, otizmli kaynaştırma öğrencilerinin bulunduğu sınıflarda grup rehberliği etkinliklerine eklenebilir ya da farklı bir program olarak kullanılabilir.

2. Etkinlik içerikleri ilköğretimin her sınıf düzeyine göre uyarlanarak kullanılabilir.

\section{KAYNAKÇA}

Attwood, T. (2000). Strategies for improving the social integration of children with Asperger syndrome. Autism: The International Journal of Research and Practice. 4(1), 85-100.

Akçamete, G. ve Ceber, H. (1999). Kaynaştırılmış Sınıflardaki İşitme Engelli Ve İşiten Öğrencilerin Sosyometrik Statülerinin Karşılaştırmalı Olarak İncelenmesi. Özel Eğitim Dergisi, 2, 64-74.

Akfırat, F. (2004). Yaratıcı Dramanın İşitme Engellilerin Sosyal Becerilerinin Gelişimine Etkisi. Özel Eğitim Dergisi, 5(1), 9-22.

Aktaş, C. ve Küçüker S. (2002), Bilişsel-Duyuşsal Odaklı Bir Programın İlköğretim Öğrencilerinin Fiziksel Engelli Yaşıtlarına Yönelik Sosyal Kabul Düzeylerine Etkisinin İncelenmesi, Özel Eğitim Dergisi, 3(2), $15-25$.

Alptekin, S. (2010), Akranların Sosyal Becerilere Model Olduğu Doğrudan Öğretimin Zihinsel Engelli Öğrencinin Sosyal Becerileri Kazanması, Sürdürmesi, Genellemesi ve Sosyal Kabule etkisi. Yayınlanmamış Doktora Tezi. Gazi Üniversitesi. Eğitim Bilimleri Enstitüsü.

Arslan, E. (2010). Kaynaştırma Uygulamalarına Katılan Engelli Öğrencilerin Sosyal Kabul Düzeylerinin Belirlenmesine Yönelik Ölçek Geliştirme Çalışması. Yayınlanmamıș Yüksek Lisans Tezi. Mehmet Akif Ersoy Üniversitesi, Sosyal Bilimler Enstitüsü.

Avcıoğlu, H. (2001). İşitme Engelli Çocuklara Sosyal Becerilerin Öğretilmesinde İşbirlikçi Öğrenme Yaklaşımı ile Sunulan Ögrretim Programının Etkililiğinin İncelenmesi. Yayınlanmamış Yüksek Lisans Tezi. Ankara Üniversitesi, Eğitim Bilimleri Enstitüsü, Özel Eğitim Anabilim Dalı, Ankara.

Avcıŏglu, H. (2005). Etkinliklerle Sosyal Beceri Eğitimi, Ankara, Kök Yayıncılık.

Baker, J. E. ( 2003). Social skills Training. For children and Adolescents with Asperger Syndrome and Social Communication Problems. Shawnee mission, KS; Autism Asperger Publishing Company. 
Batu, S. (2000). Özel Gereksinimli Öğrencilerin Kaynaştırıldığı Bir Kız Meslek Lisesi Öğretmenlerinin Kaynaştırmaya İlişskin Görüş ve Önerileri, Eskişehir; Anadolu Üniversitesi Yayınları.

Batu, S. ve Kırcaali-Iftar, G. (2006). Kaynaştırma. Ankara: Kök Yayıncılık.

Bauminger, N., \& Kasari, C. (2000). Loneliness and friendship in high functioning children with autism. Child Development, 71(2), 447-456.

Bauminger, N., Schulman, C., \& Agam, G. (2003). Peer interaction and loneliness in high-functioning children with autism. Journal of Autism and Developmental Disorders, 33(5), 489-507, DOI: 10.1023/A:1025827427901

Civelek, A. H. (1990). Eğitilebilir Zihinsel Özürlü Çocukların Sosyal Kabul Görmelerinde Normal Çocukların Bilgilendirilmelerinin ve İki Grubun Resim-iş ile Beden Eğitimi Derslerinde Bütünleştirilmelerinin Etkileri. Yayımlanmamış Doktora Tezi. Ankara Üniversitesi Sosyal Bilimler Enstitüsü.

Connor, M. (2000). Asperger syndrome (autistic spectrum disorder) and the self-reports of comprehensive school students. Educational Psychology in Practice, 16, (3), 285-295.

Cook, B. G., \& Semmel, M. I. (1999). Peer acceptance of included students with disabilities as a function of severity of disability and classroom composition. Journal of Special Education, 33(1), 50-61.

Çifci, İ. (2001). Zihinsel Engelli Bireyler İçin Hazırlanan Bilişsel Süreç Yaklaşımına Dayalı Sosyal Beceri Programının Etkililiğinin İncelenmesi. Doktora tezi, Ankara Üniversitesi Sosyal Bilimler Enstitüsü.

Çolak, A. (2007). Kaynaștırma Uygulanan Bir İlköğretim Sinıfindaki Sosyal Yeterlilik Özelliklerinin Betimlenmesi ve İyileştirilmesi Çalışmaları. Yayınlanmamış Doktora Tezi. Anadolu Üniv. Eğt. Bilimleri Enstitüsü.

Donnelly, J. \& Bovee, J. P. (2003). Reflection on play: Recollection from a mother and her son with Asperger Syndrome. Autism 7, 471-476.

DiSalvo, C. A., \& Oswald, D. P. (2002). Peer-mediated interventions to increase the social interaction of children with autism: Consideration of peer expectations. Focus on Autism and Other Developmental Disabilities, $17,198-207$.

Farmer, W. T., Pearl, R. \& Acker, R. M. V. (1996). Expanding the social skills deficit framework: A developmental synthesis perspective, classroom social networks and implications for the social growth of students with disabilities. Journal of Special Education, 30(3), 232-256.

Farrel, P. (2000). The impact of research on developments in inclusive education. International Journal of Inclusive Education, 4, 153-162.

Girli, A. ve Atasoy, S. (2012). The views of students with intellectual disabilities or autism regarding their school experience and their peers in inclusion. Buca Eğitim Fakültesi Dergisi 32, 16-30.

Goldstein, H., \& Cisar, C. L. (1992). Promoting interaction during sociodramatic play: Teaching scripts to typical preschoolers and classmates with disabilities. Journal of Applied Behavior Analysis, 25(2), 265-280.

Gordon, A.P., Feldman, D., \& Chiriboga, J. (2005). Helping children with disabilities develop and maintain friendships. Teacher Education and Special Education: The Journal of the Teacher Education Division of the Council for Exceptional Children, 28(1),1-9.

Hogborg, W (1987). Hearing-impaired students and sociometric ratings: an exploratory study. The Volta Review, 89(4), 221-228.

Harrover, J. K., \& Dunlap, G. (2001). Including children with autism in general education classrooms. Behavior Modification, 25 (5), 762-784.

Kabasakal, Z., Girli, A., Sencar, B., Çelik, ve N. Vardarlı, G. (2008). Kaynaştırma Öğrencileri, Akran İlişkileri Ve Akran İstismarı. Buca Eğitim Fakültesi Dergisi. 23, 169-177.

Kargın, Tç, Acarlar, F. ve Sucuoğlu, B. (2003). Öğretmen, Yönetici Ve Anne-Babaların Kaynaştırma Uygulamalarına İlișkin Görüşlerinin Belirlenmesi. Özel Eğitim Dergisi, 4(2), 55-77

Kamps, D., Leonard, B. R., Vernon S., Dugan, E. P., \& Delquadri, J. C.(1992). Teaching social skills to students with autism to increase peer interactions in an integrated first-grade classroom, Journal of Applied Behavior Analysis, 25, 281-288.

Krahe, B., \& Altwasser, C. (2006). Changing negative attitudes towards person with physical disabilities. Journal of Community \& Applied Social Psychology, 16, 59-69.

Lane L. K. (2004). Teacher expectation of student behavior: social skills necessary for success in elementary school classroom. Journal of Special Education (online). Available: http: // www.findarticles.com/ p/articles/mi_m0HDF/is_2_3 8/ai_n6143644.

Leaf, J. B., Taubman, M., Bloomfield, S., Palos-Rafuse, L., Leaf, R., Mc Eachin, J. \& Oppenhaim, M. L. (2009). Increasing social skills and pro-social behavior for three children diagnosed with autism through the use of a reaching package. Research in Autism Spectrum Disorders. 3, 275-289. Journal homepage: http://ees.elseiver.com/RASD/default.asp.

Lewis, R. B. \& Doorlag, D. H. (1999). Teaching Special Students in General Education Classrooms. New Jersey, Merrill an Imprint of Prentice Hall. 
Manetti, M., Schneider, B.H. \& Siperstein, G. (2001). Social acceptance of children with mental retardation: testing hypothesis with an Italian sample. International Behavioral Development. 25(3), 279-286.

Matson, J. L., Matson, M. L. \& Rivet, T. T. (2007). Social-skills treatments for children with autism spectrum disorders. An overview. Behavior Modification. 31, 5, 682-707.

Milli Eğitim Bakanlığı (2006). Özel Eğitim Hizmetleri Yönetmeliği. http//orgm.meb.gov.tr/mevzuat/ ozelegitimyonetmeligi.html.

Odom, S. L \& Strain, P. S. (1984) Peer mediated approaches to promoting children's social interaction: a review. American Journal of Orthopsychiatry, 54(4), 544-557.

Odom, S. L. (2002). Narrowing the question; social integration and characteristics of children with disabilities in inclusion settings. Early Childhood Research Quarterly, 17, 167-170.

Osler, A., \& Osler, C. (2002). Inclusion, exclusion and children's rights, Emotional and Behavioral Difficulties, 7 (1), 35-54.

Öner, N. (2006) Türkiye'de Kullanılan Psikolojik Testlerden Örnekler. İstanbul: Boğaziçi Üniversitesi Yayınları.

Özyürek, M. (2000) Tutumlar ve Engellilere Yönelik Tutumların Değiştirilmesi, Ankara; Karatepe Yayınları.

Peck, C.A., Carlson, P., \& Helmstetter, E. (1992). Parent and teacher perceptions of outcomes for nonhandicapped children enrolled in integrated early childhood programs: A statewide survey. Journal of Early Intervention, 16 (1), 53-63.

Roeyers, H. (1995). A peer mediated proximity intervention to facilitate the social interactions of pupils with pervasive developmental disorder. British Journal of Special Education, 22, 161-4.

Şahbaz, Ü. (2007). Normal Öğrencilerin Kaynaştırma Sınıflarına Devam Eden Engelli Öğrenciler Hakkında Bilgilendirilmelerinin Engellilerin Sosyal Kabul Düzeylerine Etkisi. Eurasian Journal of Educational Research, 26, 199-208.

Salend, J. B. (1998). Effective Mainstreaming. New Jersey, Merrill, an Imprint of Prentice Hall.

Sasso, G. M., Simpson, R. L. \& Novak, C. G., (1986) Procedures for facilitating integration of autistic children in public school settings. Analysis and Intervention in Developmental Disabilities, 5(3), 233-246.

Schwartz, I. (2000). Standing on the shoulders of giants: looking ahead to facilitating membership and relationship for children with disabilities. Topics in Early Childhood Special Education, 20 (2), 123-128.

Staub, D., Peck C.A., Gallucci, C. \& Schwartz, I. S. (2000) Peer relationships. In M. Snell \& F. Brown (eds.), Instruction of students with severe disabilities (pp. 381-408). Upper Saddle River, New Jersey: Merrill.

Slaughter, V., Dennis, M.J. \& Pritchard, M. (2002). Theory of mind and peer acceptance in preschool children. British Journal of Developmental Psychology, 20, 545-564.

Sucuoğlu, B. ve Kargın, T. (2006). İlköğretimde Kaynaştırma Uygulamaları, İstanbul, Morpa Yayınları.

Sucuoğlu, B. \& Özokçu, O. (2005). Kaynaştırma Öğrencilerinin Sosyal Becerilerinin Değerlendirilmesi. Özel Eğitim Dergisi, 6(1): 41-57.

Tekin, E. (1994). The Effects of Exposure to Information Techniques on Forth Grade Children's Social Acceptance Level of Exceptionality. Yayımlanmamış Yüksek Lisans Tezi. Orta Doğu Teknik Üniversitesi Sosyal Bilimler Enstitüsü.

Terpstra, J. E. \& Tamura, R. (2008). Effective social interaction strategies for inclusive settings. Early Childhood Education, 35, 405-411.

Uçar, C. (2008). Farklı Gelişenleri Kabul Edici Tutum Geliştirme Programının Normal Gelișen Öğrenci Tutumlarının Gelişimine Etkisi. Yayınlanmamış Yüksek Lisans Tezi. Marmara Üniversitesi Eğitim Bilimleri Enstitüsü, İstanbul.

Vickerstaff, S., Heriot, S., Wong, M., Lopes, A., \& Dossetor, D. (2007). Intellectual ability, self-perceived social competence, and depressive symptomatology in children with high-functioning autistic spectrum disorders. Journal of Autism and Developmental Disorders, 37(9), 1647-1664. DOI: 10.1007/s10803006-0292-x.

Vuran, S. (2005). The sociometric status of student with disabilities in elementary level integration classes in Turkey. Eurasian Journal of Educational Research, 18, 217-235.

Webster, A. A. \& Carter, M. (2007). Social relationships and friendships of children with developmental disabilities: Implications for inclusive settings. A systematic review. Journal of Intellectual and Developmental Disability, 32 (3), 200-213.

Yaşaran, Ö., Ö., ( 2009). Normal Gelişim Gösteren Öğrencilerin Özel Gereksinimli Bireylerin Sosyal Kabullerini Sağlamada Kaynaştırmaya Hazırlık Etkinliklerinin Etkisi. Yayınlanmamış Yüksek Lisans Tezi. Anadolu Üniversitesi, Eğitim Bilimleri Enstitüsü.

Yıldırım, A., ve Şimşek, H. (2000). Sosyal Bilimlerde Nitel Araştırma Yöntemleri. Ankara: Seçkin Yayınları. 


\section{Ek:1. Öğretmen Gözlem ve Görüşme Formu}

1. Otizmli kaynaştırma öğrenciniz akranları tarafından teneffüslerde oyunlara davet edilir mi?

2. $\quad$ Otizmli kaynaştırma öğrenciniz ortak projelerde grup arkadaşı olarak seçilir mi?

3. Yakın arkadaşı var mı? Sınıfta kaç arkadaşı onunla oyun oynar?

4. Akranları onunla alay eder mi? / Ederse hangi konularda?

5. Kaynaştırma öğrencisi kendiliğinden oyuna katılmayı teklif eder mi?

6. Arkadaşlıkları ne kadar sürer? Neden sona erer?

7. Akranlarıyla sorun yaşar mı? / yaşarsa ne tür sorunlar yaşar? / Ne zamanlar yaşar?

8. Akranları arasında nasıl davranır? Gruba katılabilir mi? Geri çekilir mi?

9. Sinıf kurallarının farkında mıdır? Uyar mı?

10. Derse katılır mı? (parmak kaldırır $\mathrm{ml}$, soru sorar $\mathrm{ml}$, soruları cevaplar $\mathrm{ml}$, masa başında uygun çalışır $\mathrm{ml}$, ödevlerini zamanında getirir mi?)

11. Oyunlarda sıra alma, paylaşma, uzlaşma ve benzeri sorunlar yaşar mı?

12. Birisini tanımak için uygun sorular sorabilir mi?

13. Diğerlerinin ilgilendikleri konuları bulabilir mi hakkında konuşabilir mi?

14. Ses tonu " ses tonu", "göz teması", "sıra alma" ve "uygun iletişim mesafesi" gibi temel sohbet becerilerini kullanabilir mi?

15. Öfkesini kontrol edebilir mi? Uygun durumlarda uygun biçimde ifade edebilir mi?

16. Diğerlerinin kişisel özelliklerine iltifat edebilir mi? 